Public-data File 89.7

SUMMARY OF ALASKA'S MINERAL INDUSTRY IN 1988

By

C.B. Green and T.K. Bundtzen

February 1989

THIS REPORT HAS NOT BEEN REVIEWED FOR TECHNICAL CONTENT (EXCEPT AS NOTED IN TEXT) OR FOR CONFORMITY TO THE EDITORIAL STANDARDS OF DGGS 


\title{
SUMMARY OF ALASKA'S MUNERAL INDUSTRY IN 1988
}

\author{
By C.B. Green ${ }^{1}$ and T.K. Bundtzen ${ }^{2}$ \\ INTRODUCTION
}

\begin{abstract}
Alaska's mincral industry expanded dramatically in 1988 with sigrificant increases in exploration and development expendirures, and in the value of mineral production. Exploration expenditures nearly uripled from $\$ 15.7$ million in 1987 to $\$ 4.5$ million in 1988 . The Greens Creek and Red Dog mines both experienced peak construction activities during the year, more than doubling development expenditures from $\$ 100.3$ million in 1987 to $\$ 269.7$ million in 1988 . The total value of mineral production increased 14 percent in 1988 to $\$ 232.2$ million led by a 16-percent increase in gold production (from 229,700 oz in 1987 to 265,500 oz in 1988) and a modest recovery of the building stone and sand and gravel industries.
\end{abstract}

The total value of Alaska's mineral industry in 1988, measured by the sum of exploration and development expenditures, and the value of mineral production, increased over 72 percent from $\$ 318.4$ million in 1987 to $\$ 546.4$ million in 1988 (table 1). The number of people employed in the various segments of the mining industry in 1988 is estimated to have increased 49 percent to 4,904 in 1988, up from 3,299 in 1987.

Table 1. Total value of mineral industy in Alaske, 1986-1988.

\begin{tabular}{lrrr} 
& \multicolumn{1986}{c}{} & $\underline{1987}$ & \multicolumn{1}{c}{1988} \\
Exploration & $\$ 8,914,744$ & $\$ 15,734,061$ & $\$ 44,503,800$ \\
Development & $24,331,972$ & $100,250,848$ & $269,745,400$ \\
Production & $198,461,007$ & $202,389,898$ & $\underline{232,172,200}$ \\
TOTAL & $\$ 231,707,723$ & $\$ 318,374,807$ & $\$ 546,421,400$ \\
& \multicolumn{2}{c}{ PRODUCTION }
\end{tabular}

Gold production again led all other mineral commodities and accounted for 49 percent of total dollar value. An estimated 265,500 oz of gold were produced and valued at $\$ 112.8$ million. This represents an increase of 16 percent by quantity and 8 percent by value over 1987 levels. USIBELLI COAL MINE, INC. shipped a record 810,862 tons of coal to the KOREAN ELECTRIC POWER COMPANY, sent 13,467 toos for testing in Japan, and 726,833 tons fueled six interior Alaska power plants. Coal production in 1988 was 1,55 million tons, for an estimated value of $\$ 4$ million--about the same as 1987 levels. Sand and gravel production was 17.2 million tons, worth $\$ 48.8$ million-again about the same as 1987 levels. Approximately 3.6 million tons of building stone worth $\$ 24.6$ million was produced in 1988, up nearly 112 percent by value from 1987 levels. Infrastructure development at the Red Dog mine and Bradley Lake bydroelectric project and at several mine sites in southeast Alaska were responsible for this increase in building stone use. Gold, coal, building stone, and sand and gravel accounted for 99 percent of the total value of Alaska mineral production in 1988. Tin, silver, tungsten, jade, platinum, soapstone, and peat accounted for the remaining 1 percent.

The increase in 1988 gold production reflected increased production from several of the largest placer operations and from two interior bard rock lode mines. The VALDEZ CREEK MINING COMPANY placer operation east of Cantwell produced 52,961 oz of gold and was Alaska's largest gold producer in 1988. Approximately 200 small gold placer operations produced at levels similar to 1987. CITIGOLD ALASKA, INC. and TRICON MINING, INC. produced 21,500 oz of gold-silver bullion from lode deposits on Ester Dome near Fairbanks.

\footnotetext{
Alaska Division of Business Development, 1001 Noble Street, Ste. 360, Fairbanks, AJaska 99701.

${ }^{2}$ Ajaska Division of Geological and Geophysical Surveys, 3700 Airport Way, Fairbants, Alaska 99709.
} 
Table 2. Reported mineral production in Alasko 1986-1989. a

\begin{tabular}{|c|c|c|c|c|c|c|}
\hline \multirow[b]{2}{*}{ Metals } & \multicolumn{3}{|c|}{ Quantity } & \multicolumn{3}{|c|}{ Estimated values ${ }^{b}$} \\
\hline & 1989 & 1987 & 1989 & 1986 & 1987 & 1988 \\
\hline Gold (oz) & 160,000 & 229,700 & 265,500 & s $60,800,000$ & $\$ 104,516,230$ & $\$ 112,837,000$ \\
\hline Mercury (lb) & 912 & NR & $\mathbf{W}$ & 2,800 & NR & W \\
\hline Antimony (fb) & 45,000 & NR & NR & 67,500 & NR & NR \\
\hline Platinum $(\propto)$ & $w$ & w & 25 & $\mathbf{w}$ & W & 13.750 \\
\hline Silver (oz) & 24,000 & 54,300 & 47,790 & 134,400 & 390,960 & 281,950 \\
\hline $\operatorname{Tin}(b)$ & 340,000 & 288,000 & 300,000 & 890,000 & 460,000 & 950,000 \\
\hline Tungsten (stu) & 120 & 160 & 240 & 2000 & 11,400 & $\underline{14,000}$ \\
\hline Subtotal & & & & $561,917,500$ & $\$ 105,378,590$ & $\$ 114,096,700$ \\
\hline \multicolumn{7}{|l|}{$\begin{array}{l}\text { Industrial minerals, coal } \\
\text { and peat }\end{array}$} \\
\hline Jade and soapstone (ton) & 2.0 & 3.6 & $w$ & 12,000 & 78,000 & $w$ \\
\hline Sand and gravel (mt) & 20.9 & 16.7 & 17.2 & $75,761,507$ & $42,659,808$ & $48,750,500$ \\
\hline Building stone (mt) & 4.2 & 1.8 & 3.6 & $20,320,000$ & $11,620,000$ & $24,650,000$ \\
\hline Subtotal & & & & s $96,093,507$ & S $\$ 4,357,808$ & $\$ 73,400,500$ \\
\hline Co:l (ton) & $1,492,707$ & $1,508,927$ & $1,551,162$ & s $40,100,000$ & S $42,354,500$ & s $44,300,000$ \\
\hline Peat $\left(y d^{3}\right)$ & 50,000 & 46,000 & 55,000 & 350,000 & 299,000 & 375,000 \\
\hline Subtotal & & & & $\$ 40,450,000$ & $1+2,653,500$ & $\$ 44,675,000$ \\
\hline TOTAL & & & & $\$ 198,461,007$ & $\$ 202,369,898$ & $\$ 232,172,200$ \\
\hline
\end{tabular}

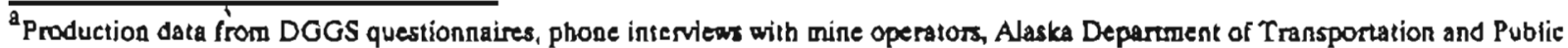
Factlities, the U.S. Amy Corps of Engineers, and other confidential sources.

b Values calculated from 1988 annual price averages of gold, silver, ard platinum; other values directly supplied by mine operators. NR = not reported; $W$ a withheld; $m t$ = million ton; stu = short-ton unil. 
Table 3. Reported refined gold production, number of operators, and industry employment in Alaska by region and mining districl. $1987-88^{\circ}$

1987

1988

Region and Number of Production Number of Number of Production Number of minine district eperators (oz) enployees

eperator (az) mployees

Northern

8

7,256

40

8

6,500

32

Chandalar

Stungnak

Koyukuk-Nolan

Western

46

101,244

414

48

98,500

425

Nome

Kougarok

Port Clarence

Fairhaven

Ruby

Solomon

Koyuk

Council

Eastera Interior

Circle

Livengood-Tolovana

Fairbanks

Fortymile

Manley-Eureka

Richardson

Bonnifield

Rampart

Southceatral

29

46,460

251

30

68,300

315

Cache Creek

Chistochina

Vaidez Creek

Kenai Peninsula

Nelcbina

Southwestern

36

20,650

129

33

14,800

108

Innoko-Tolstoi

Iditarod-George River

Moore Creek

Nyac

Crooked Creek

Lake Clark-Mulchatra

Soutbeastern and

Alaska Peniosula

5

3,400

35

3

$\underline{850}$

10

TOTAL

229,700

1,249

211

265,500

1,305

\footnotetext{
"1988 producsion estimated from 208 mechenized placer mines and three fode mines statewide. Small 'recreational-assessment' projects that recover buflion from panning, plek-and-shovel prospecting, long-tom sluicing and suction dredging are not included.
} 


\section{DEVELOPMENT}

Both the Greens Creek and Red Dog mine projects underwent peak construction activities during 1988. An estimated $\$ 269$ million were spent in 1988 for the construction of roads, and port, mine, mill and camp facilities at those mine sites.

Greens Creek, located on Admiralty Island near Juneau, will begin production in early 1989 and, at full capacity, is designed to produce 85,000 tons of conceatrate amually, containing an estimated 6.4 million oz of silver, 36,000 oz of gold, 24,800 tons of zinc, and 9,000 tons of lead. The mine will become the first major lode producer in Alaska for four decades. The joint venture project is operated by the GREENS CREEK MINING COMPANY, a subsidiary of BP MINERALS AMERICA. The joint venture parteers include BP MINERALS AMERICA (53.1 percent), HELCA MINING (28.0 perceat), CSX OLL AND GAS CORPORATION (12.6 percent), and EXALAS RESOURCES (6.3 percent). When fully operational, Greens Creek will fill over 200 year-round positions with workers living in the Juneau area and commuting daily to the mine on a specially constructed caramaran ferry.

Construction activities in 1988 brought the Red Dog project, located 90 mi north of Kotzebue in the De Long Mountains, to 60-percent completion. The Red Dog deposit is owned by the NANA REGIONAL CORPORATION and operated by COMINCO ALASKA INCORPORATED. During 1988, the 52-mi road from the port site near Kivalina to the mine site was completed. At the port site, construction of the concentrate storage building fuel tanks, and ship loading facilities was undertaken. At the mine site, the camp accommodations and mine services buildings were constructed, the fondation for the concentrator mill prepared, and earthwork done at the main pit and tailings impoundment dam. During 1988, an estimated 1,000 people were employed on the construction of the road, port, and mine site. Start-up of the mine is scheduled for early 1990, with the first concentrate shipments to be made during that summer. At full capacity, the mine will produce 580,000 ton/yr of zinc concentrate, 120,000 ton/yr of lead concentrate, and 50,000 ton/yr of concentrate suitable for feed to an Imperial smelter furnace.

\section{EXPLORATION}

Exploration activities in Alaska increased significantly in 1988, with expenditures totaling $\$ 44.5$ million, an increase of 184 percent over 1987. Reported exploration employmeat increased 147 percent to a total of 2,780 person-months, from 1,126 persod-months in 1987. As in previous years, the primary focus of exploration programs was precious metals. Over 90 percent of all expenditures were for precious metal exploration, with expenditures for coal and base metal exploration representing 6 percent and 3 percent, respectively.

Southeast Alaska was the most active region in the state in terms of expenditures and employment. Over $\$ 20$ million was spent and 1,200 person-months of employment were reported in the region, representing 46 percent of statewide exploration project expenditures. Several southeastern exploration projects advanced to the point where feasibility studies, and preliminary environmental baseline and perwitting activities, will be undertaken in 1989. These include the AJ Mine and Kensington Mine projects operated by ECHO BAY MINES and the Jualin Mine project operated by CURATOR AMERICAN. Other notable lode gold projects with significant exploration drilling programs in the region were carried out by LAC MINERALS, NEWMONT GOLD, and FMC GOLD. While much additional exploration activity is focusing on the reexamination of historical mines and properties in the region, grass-roots exploration efforts resulted in significart new mineral discoveries in 1988.

All other regions of the state experienced significant increases in exploration activity. Notable projects with major exploration drilling programs on lode gold deposits were carried out by PLACER DOME, SOLOMON GOLD, and BHP UTAH INTERNATIONAL near Nome in the western region; by TRICON MINING, NERCO MINERALS, AMERICAN COPPER \& NICKEL, and BP MINERALS in the eastern interior region; by BATTLE MOUNTAIN and COMINCO in the southwestern region; by GOLDEN ZONE RESOURCES, COMINCO, AMAX EXPLORATION, and HUNT, WARE \& PROFFETT in the southcentral region; and by BATTLE MOUNTAIN and ASHTON MINING in the Alaska Peninsula region. 
In coal exploration, DEMITSU ALASKA INC carried out a major progeram on its state leases in the Matanuska coulfield sear Palmer. In June 1988, IDEMITSU announced that UNION PACIFIC RESOURCES, its partner in the project, had withdrawn. DEMITSU acquired UNION PACIFTC'S interest, and, under a preliminary projeer schedule, could complete project permirting in 1990 and could begin export in 1991 of up to 1.1 million ton/yr of bituminous coal to Japan.

Table 4. Repored Alaske mineral eploration ependitures by region 1986-88"

\begin{tabular}{|c|c|c|c|}
\hline Region & 1986 & 1987 & 1988 \\
\hline Northern & S 601,000 & 5621,000 & $\$ 993,000$ \\
\hline Western & 582,800 & $1,176,500$ & $3,836,550$ \\
\hline Eastem interior & $2,378,174$ & $3,337,931$ & $6,163,100$ \\
\hline Southcentral & $2,408,850$ & $3,430,470$ & $9,187,650$ \\
\hline Southwestern & 176,200 & 615,000 & $1,885,000$ \\
\hline Southeastera & $2,746,220$ & $5,846,000$ & $20,641,500$ \\
\hline Alaska Penirsula & 21.500 & 207,160 & $1.797,000$ \\
\hline & $\$ 8,914,744$ & $\$ 15,734,061$ & $\$ 44$, \\
\hline
\end{tabular}

\section{GOVERNMENT ACTIONS}

Several significant legal or governmental actions affecting Alaska's mineral industry took place in 1988. The U.S. Supreme Court declined to hear the State of Alaska's appeal of the Alaska Supreme Court's interpretation of section 6(i) of the Alaska Statehood Act. As a result, the 1989 Alasks legislature will be amending certain state laws governing the location of state mining claims, addressing the implementation of rental and royalty fees, and determining which state lands will be subject to the new laws.

The Alaska Department of Environmental Conservation adopted new mixing zone water quality regulations in 1988 that may help placer miners and other industrial water users comply with the state's turbidity standards. Guidelines are being developed to allow the new regulations to be tested in 1989 and implemented in the 1990 season. The federal Environmental Protection Agency issued effluent guidelines for placer mining, which will go into effect is 1989 and will require 100-percent recycling of mine process waters for the placer mining industry. The 1989 Placer Mining Conference, to be beld in Fairbanks March 29.April 1, 1989, will focus on the mine water recycling and reclamation technologies currently in use aationwide.

In federal action, the U.S. Bureau of Land Management (BLM) completed draft eavironmental impact statements (EIS) on the cumulative effects of placer mining on four interior Alaska river drainages. In late 1988, the first of the final EIS's to be issued identified a preferted alternative that proposed allowing placer mining to continue under management policies adopted in 1987. As part of the federal court order that mandated the preparation of the EIS's, an injunction was granted against the operation of placer mines disturbing more than five acres. A record of decision by the Secretary of the interior on the EIS's is expected in early 1989; however, the lifting of the injunction will be at the discretion of the federal courts. in a similar action, the National Park Service is in its third year of preparing a court ordered EIS on mining in Alaska's National Parks, where aل mining has been indefinitely balted since 1985.

In late 1987, the U.S. Minerals Management Service took steps to hold a lease sale for the mining of gold and other minerals on submerged federal lands in Norton Sound. The proposed federal lease tracts are located adjacent to state offshore leases where WESTGOLD is presently operating the Bima bucketline dredge. The draft EIS for the lease sale was completed in November 1988, and the preferred alternative identified 178,282

\footnotetext{
aoth regional and statewide totals are presiminary for 1988 and will be updated in the final report.
} 
actes of outer continental shelf lands for leasing The final EIS is expected to be complete in May 1989. If a decision is made to proceed with the sale, a nocice would be published in Oesober 1989, with the lease sale scheduled for laee 1989. 